\title{
Entrepreneurs' resilience to natural disasters: a survey in the retail sector
}

\author{
Elisa Martinelli - Giulia Tagliazucchi
}

\begin{abstract}
Purpose of the paper: The paper is aimed at studying entrepreneurs' resilience to natural disasters by verifying the impact of some of the main determinants of the resilience capacity of small retailers who were affected by the 2012 Emilia earthquake.

Methodology: The research consisted in administering a structured questionnaire to a sample of small retailers who were affected by the earthquake. Data was processed applying a hierarchical multiple regression.

Findings: Findings show that all the investigated constructs exerted a significant and positive effect on the resilience capacity of small retailers. The greatest impact is exerted by market orientation and individual resilience. Control variables like gender, age and education, apart from the possession of a graduate degree, did not exert any effect.

Research limits: The paper consists in a preliminary study that is explorative in nature. Future studies should consider additional organizational resilience antecedents such as different configurations of retailers' resources and competences.

Practical implications: A deeper knowledge on organizational resilience antecedents could enable small retailers to better evaluate their investments and understand with which kind of abilities/competences they should be equipped in order to face natural disasters. Managerial implications are complemented by public policy recommendations.

Originality of the paper: In the management literature, the study of entrepreneurs' resilience to natural disasters in small firms, and retailing in particular, is limited. Empirical research is also lacking, apart from a small number of qualitative studies. Our paper aims at filling these gaps by reporting the preliminary findings of a quantitative survey.
\end{abstract}

Key words: resilience; natural disasters; small retailers; earthquake

\section{Introduction}

Natural disasters are destructive events of increasing manifestation all over the world. This is also true in Italy, a country affected by growing environmental fragility, where floods, earthquakes, and other natural events are increasingly frequent and disruptive. In particular, in the 20022017 period, Italy was affected by 9 major natural disasters estimated on the basis of data provided by the European Commission, which caused damages amounting to 49.9 billion euros (AdnKronos, 2017). The impact of these disasters varies: although they fortunately do not always cause loss 
sinergie Vol. 37, Issue 1, 2019

of lives, the economic and social environment is strongly compromised, with considerable damages to economic activities and the community. In fact, at a micro level, natural disasters represent a potentially unpredictable and burdensome threat for the continuity of a company's activities and its survival. To date, studies analyzing the effects of natural disasters on small businesses are still limited (Chang and Falit-Baiamonte, 2002; Dahles and Susilowati, 2015; Deitch and Corey, 2011; Kroll et al., 1990; Liu et al., 2012; Parker et al., 2009; Webb et al., 2000), particularly when retailing activities are concerned, despite the central role of this sector in the recovery process after a catastrophic event (Baker et al., 2007; Liu et al., 2012). In fact, while an easy access to commercial services is taken for granted in everyday life, the role of the retail sector is crucial during times of crisis, due to its ability to provide support and first aid (Peterson et al., 2010). Analyzing the limited contributions that have dealt with resilience and the impact of natural disasters on retailing and especially small businesses, various consequences might be identified: direct damages to the store; indirect damages to the retail activity; changes in purchasing behavior. Moreover, the ways in which retail entrepreneurs react and adapt to the changed conditions of the affected territory inevitably influence the development paths of their businesses.

In this context, this paper aims at studying entrepreneurs' resilience to natural disasters by verifying the impact of some key dimensions on the resilience capacity of a sample of small retailers who were affected by the earthquake that affected the Emilia region in 2012. The destructive force of the earthquake, the characteristics of the affected territory and the direct and indirect damages that were caused make this natural disaster an interesting case study. Through a survey based on the administration of a structured questionnaire to a sample of small retailers, the study aims to verify how the typical abilities that should distinguish a retailer - namely, sales capabilities, market orientation, the degree of individual resilience and the support of social capital - might impact on the resilience capacity of retail entrepreneurs. Although natural disasters of immediate destructive impact (Cutter et al., 2008) - such as earthquakes, hurricanes, floods require a sudden response, whether an individual, territory, community or organization was prepared to cope with it (Bharma et al., 2011) and acted resiliently can only be assessed afterwards. Therefore, we consider it essential to evaluate the actions put in place by the entrepreneurs who, upon being affected by a natural disaster, acted promptly and resiliently, continuing their business activity and, in some cases, improving it five years later. Implications are not only managerial, but also related to public policies, guiding institutions that should support the development of adequate capacities to prevent and respond to this type of disaster.

The present work is structured as follows: after analyzing the literature on resilience and natural disasters and its contextualization in the retail sector, the fourth paragraph presents the model and the research hypotheses; the fifth outlines the adopted methodology. Subsequently, survey results are presented and discussed along with conclusions and the study's limitations. 


\section{Resilience and natural disasters}

The academic literature dealing with natural disasters has only recently begun to place companies at the center of the analysis (Zhang et al., 2009) by highlighting how small businesses are usually the most severely affected due to a greater incidence of the direct and indirect damages that are caused by catastrophic events (Webb et al., 2000; Alesch et al., 2001). A natural disaster, in fact, produces a direct effect on economic activities, causing physical damages to plants, capital goods and equipment and partially or totally damaging stored stocks and products. Such direct damages, if substantial, can even lead to the interruption of business activities for long periods of time, thus putting businesses survival at risk. The occurrence of a natural disaster could also result in the disruption of key external services, including communication lines, gas, water and electricity supplies, logistics and transport infrastructures (Tierney, 1997; Wasileski et al., 2011; Zhang et al., 2009). Moreover, its indirect effects are also numerous and variable such as population migration, as people tend to leave affected territories. Therefore, the business activity's continuity is not to be taken for granted.

According to Alesch et al. (2001), in order to consider a business as recovered after a natural disaster, it is necessary for that activity to remain located in the affected territory for a significant period of time after the disruptive event, and for this permanence to be associated with a profit condition that is in line with the changed economic conditions of the area, even if it is not necessarily in line with pre-disaster levels. However, business continuity is not always synonymous of a resilient activity, although, generally speaking, this term is used to indicate the capacity characterizing systems, individuals and organizations to resist, react to and recover from a critical event that puts their stability and functioning at risk, thus minimizing its effects (Linnenluecke, 2017; Sutcliffe and Vogus, 2003; Williams et al., 2017). However, in the organizational literature, resilience cannot only be interpreted as the recovery capacity to return to a pre-existing state, as the ecological (Holling, 1973) and systemic social-ecological (Walker et al., 2004) perspectives state. In fact, resilient actions should also be aimed at taking advantage of challenges to increase resources and capabilities. Accordingly, resilience implies the possibility of developing new skills and creating new opportunities (Sutcliffe and Vogus, 2003; Lengnick-Hall and Beck, 2003; Lengnick-Hall et al., 2011; Martinelli et al., 2018), to dynamically relate with the environment (Williams et al., 2017). This is a capability that is not only related to the response to and absorption of changes, but also to the maintenance, recovery and development of fresh resources and skills. By acting in a resilient way, businesses might not only minimize the impact of negative events like natural disasters, but also ensure the continuity of their activity and, above all, renew and develop it compared to its state of being before the onset of the critical event (Kantur and İşeri Say, 2012).

In the managerial field, several studies have attempted to identify resilience dimensions. Among these, Kantur and İşeri Say (2012) theorize an integrated model in which organizational resilience, defined on the 
sinergie Vol. 37, Issue 1, 2019

basis of dimensions that had been previously proposed by Bruneau et al. (2003), i.e. Robustness, Redundancy, Resourcefulness, Rapidity, was preceded by four specific antecedents: awareness of the organization's strengths and weaknesses; degree of involvement of the actors within the company when searching for creative solutions; ability to exploit tangible and intangible resources in order to transform adverse conditions into new growth opportunities; pro-active actions in the development of innovative solutions in response to a critical event.

\section{Resilience in the retail sector}

The analysis of the literature reveals the lack of studies that are specifically aimed at investigating resilience at the retail level, especially as regards natural disasters. The retail sector shows a greater level of vulnerability compared to other sectors (Wasileski et al., 2011; Webb et al., 2002). Previous studies have highlighted how the retail and service sectors tend to perform worse compared to the manufacturing and building sectors. This also happens in the case of an earthquake: the Loma Prieta earthquake had a strong impact on retailing and services (Kroll et al., 1990); similarly, a large percentage of retail businesses suffered significant economic losses in Seattle following the 2001 Nisqually earthquake (Chang and Falit-Baiamonte, 2003). This vulnerability is due to the greater impact of indirect damages: in addition to the direct damages suffered by stores, equipment and stocks, the retail sector is heavily influenced by the affected populations' lower propensity to purchase (Meszaros, 2002), by consumption adjustment trends and changes in demand preferences (Frank and Schvaneveldt, 2016). Among possible indirect damages, the reduction in sales resulting from the decrease in buying that is caused by the transfer of the population and the generalized lower propensity to purchase following a natural disaster (Zhang et al., 2009), is one of the biggest challenges faced by small retailers. Alongside this, the businesses' small size is usually accompanied by lower economic resources, as opposed to franchise-affiliated operators who may have greater access to financial capital (Runyan, 2006).

Despite this, some studies have shown that the retail sector is the first to stabilize about one year after a critical event, even if on lower levels and with a marked loss of small businesses (Wasileski et al., 2011). This recovery is driven by the central role that the local retail network plays in the immediate post-disaster period/phase: once the emergency phase is over, consumption allows the local community to return to a certain degree of normality and achieve a new equilibrium (Baker et al., 2007; Liu et al., 2012). In the medium to long term, however, the effects of natural disasters on the retail structure can be substantial. For example, the study by Pearson et al. (2011), conducted on the retail trade five years after Hurricane Katrina, highlighted a sharp decline in the number of retailers. In this specific case however, the drivers of this effect were different. Firstly, the level of debt, linked to a rapid recovery in business activity, was unsustainable in the medium run. Secondly, the decrease in population 
resulted in a reduction in demand, with the consequent closure of some sales outlets. Furthermore, an excess in distribution offer, in relation to the number of residents, took place and these are only some of the possible consequences that retailers have to face. They have also to cope with changed purchasing patterns in the post-disaster phase/period, including a decrease in the purchase of luxury goods (Meszaros, 2002, Zhang et al., 2009), higher price consciousness and a consequent replacement of goods with cheaper products, and an increase in "do-it-yourself" solutions (Liu and Black, 2011).

In spite of what has been stated so far, natural disasters, if properly addressed, can also be a source of new and potential opportunities. For example, it has been observed that the retailers who are able to reopen in the immediate post-calamity period/phase recorded a significant increase in sales due to the presence of fewer competitors (Runyan, 2006). Furthermore, retailers who displayed socially responsible behaviors by putting themselves at the service of a population that has been struck by a natural disaster and guaranteeing continuity in their commercial service at the expense of profit, were rewarded by customers with a higher retention rate (Liu et al., 2012). The role played by the behaviors that were implemented by retailers during the emergency phase emerged as a key tool to their business recovery in the long-term. Last but not least, small retail entrepreneurs' features play an important role: Teece (2012) argues that the smaller the size of a business, the greater the probability that its capabilities depend on one or a few individuals; it is therefore essential to evaluate the individual resilience of the retail entrepreneur in addition to the firm's characteristics.

\section{Model and hypotheses}

The objective of the study is to explore the construct of organizational resilience in its constitutive dimensions. Since resilience is a latent characteristic, this potential capacity can only be grasped and analyzed when it occurs (Linnenluecke, 2017). Similarly to previous studies (Pearson et al., 2011), the actions that were undertaken at the time of the natural disaster were reconstructed five years later in order to evaluate the effectiveness of the strategies that were implemented and the resilience capacity that was displayed by small retailers. The 2012 earthquake in Emilia acts as a natural experiment and a reference context for the survey.

An analysis of the academic literature on the subject has highlighted that different dimensions impact on organizational resilience. As shown in Figure 1, the proposed model is based on the synergistic action of several factors: sales capacity; market orientation; social capital; the individual approach of the entrepreneur, conceptualized as individual resilience. The items that were used for the analysis of the organizational resilience construct and its dimensions derive from scales that have been tested by the academic literature, translated appropriately and adapted to the context of small retail businesses. The latent investigated variables were then evaluated and analyzed by means of a 7-point Likert scale whose reliability analysis may be found in Table 4 .
Elisa Martinelli 
sinergie Vol. 37, Issue 1, 2019

The organizational resilience construct was measured by adopting the scale tested by Kantur and İsseri Say (2015), who first proposed a measurement scale focused on resilience capacity, where elements linked to the robustness of a company facing a critical event and its ability to easily and quickly adapt to new environmental conditions are of key importance. This is therefore the dependent variable of the proposed model.

Previous empirical studies stated that a retailer's behavior and the strategies that are adopted in the immediate post-calamity period/ phase are key factors in determining the path of recovery. In particular, a retailer's market orientation, i.e. the capability to read and pro-actively adapt to changes in the needs and desires of the demand in terms of the offered assortment and level of service - and his/her sales capacity, i.e. the retailer's ability to generate sales - are considered particularly important in addressing the direct and indirect effects of earthquakes (Pearson et al., 2011), as well as changes in the post-disaster demand (Meszaros, 2002; Zhang et al., 2009).

Firstly, market orientation strategies taking the changed economic conditions of the affected population into account and focused on service continuity can be rewarded by customers with a higher retention rate (Liu et al., 2012). This dimension was measured on the basis of the scale proposed by Verreynne (2016) by isolating items focused on market analysis capabilities and on the assessment of emerging conditions and opportunities. In particular, this dimension is aimed at investigating the ability to grasp new market opportunities and quickly interpret changes in demand, as well as the tendency to experiment with new ways of providing retail service and changing the product/service offer.

Secondly, given the changes in demand and purchase preferences that characterize post-calamity phases (Liu and Black, 2011), we believe that entrepreneurs' sales skills can play a fundamental role in supporting a business' recovery. As a preexisting skill and part of the professional background, this element was determined by asking the interviewees to evaluate a series of performance indicators of their business activity in relation to who the respondent believes his or her main competitor to be, in particular with reference to the ability to increase sales from one year to another and the average level of turnover.

H1: The sales capabilities of a retailer have a significant and positive impact on organizational resilience.

H2: The market orientation of a retailer has a significant and positive impact on organizational resilience.

Additionally, as highlighted in the previous paragraph, in the case of small businesses, the resilience of an enterprise is closely linked to the individual resilience of its entrepreneur (Teece, 2012). It was therefore considered appropriate to insert items that could capture this element. In particular, a scale taken from the individual psychological literature and widely used in other studies on the effects of natural disasters (Connor and Davidson, 2003) was employed. 
H3: The retailer's individual attitude has a significant and positive impact on organizational resilience.

Lastly, the importance of social capital has been highlighted in a series of studies (Pal et al., 2014; Lengnick-Hall and Beck, 2005) that underline the role of relationships between individuals, which are based on reciprocity and trust, as a reservoir of additional resources and skills to draw from in case of need. Organizational resilience might also depend on the ability to cultivate relationships based on trust and support within the network of individuals and companies with whom retailers interact (relatives, friends, acquaintances, customers and suppliers). In the extant literature this relational factor is referred to as social capital and expresses the support and help that can be provided by those who are part of a certain network in case of critical events (Dubini and Aldrich, 1991), thus allowing the mobilization of resources (Adler and Kwon, 2002). In assessing the importance of social capital, it could be helpful to consider, for example, benefits linked to a supplier-retail relationship based on trust: in the case of a natural disaster, the willingness of some suppliers to extend payment terms/deadlines or suspend invoices during the emergency period has been observed (Chamlee-Wright and Storr, 2014; Martinelli et al., 2018). To analyze this constitutive dimension of organizational resilience, a scale that has been validated by Makkonen et al. (2014) was employed, extracting only items relating to the networks of personal and professional relationships that the retail entrepreneur has been able to activate and develop over time.

H4: Social capital has a significant and positive impact on organizational resilience.

For each component listed above we expect to find a direct and positive effect on organizational resilience, as shown in Figure 1 below. In the model, some control variables related to the socio-demographic features of the sample of investigated entrepreneurs, namely gender; age class; education, were included.

Fig. 1: Organizational resilience dimensions

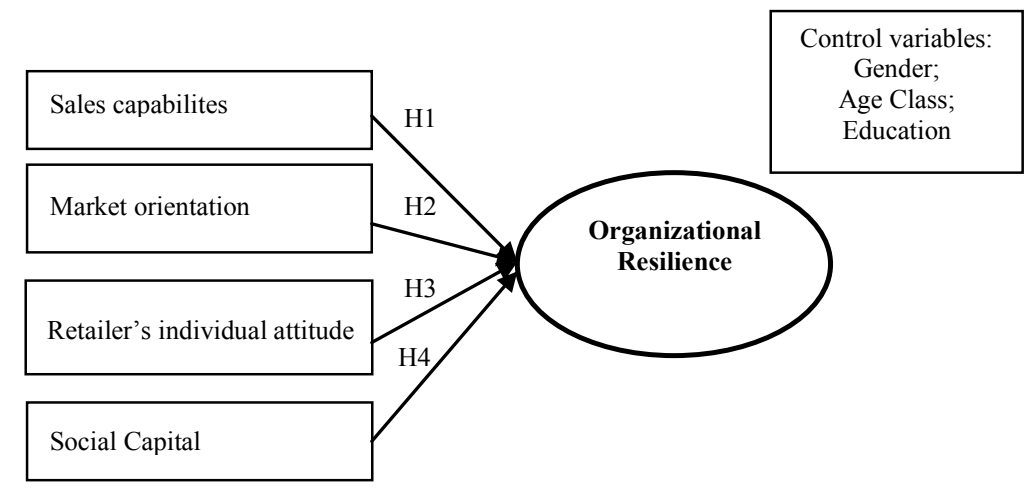

Source: authors' elaboration
Elisa Martinelli

Giulia Tagliazucchi

Entrepreneurs' resilience to natural disasters: a survey in the retail sector 


\section{Sinergie}

Vol. 37, Issue 1, 2019

\section{Methodology}

\subsection{The context of the analysis: the 2012 earthquake in Emilia}

The earthquake that affected the Emilia region in 2012 represents an interesting context of investigation for the purposes of this study.

The earthquake struck in two waves of intense intensity. The first shock occurred on May 20th, 2012 (magnitude ML 5.9) and the second on May 29th, 2012 (ML 5.8), causing 28 deaths and 300 injured, 45,000 displaced persons, and damages amounting to around 13 billion euros (Emilia Romagna Region, 2017a).

The effects of this earthquake were amplified by various factors. Firstly, the affected territory was not classified as potentially seismic, making the calamity completely unexpected. Secondly, the disaster was combined with the effects of the economic crisis that was under way at the time and had already considerably weakened the local economic system and smaller businesses in particular. Thirdly, it was the first time that an earthquake occurring in Italy had affected a highly industrialized area: the Emilia region was one of the most productive and densely industrialized in the country, with important consequences on the Italian economy as a whole. In fact, the affected area provides $2 \%$ of the Italian GDP, thanks to the numerous companies and industrial districts with an international presence.

The sectors that were most affected were the biomedical and textile ones, along with the retail sector (Emilia Romagna Region, 2012). In the five years following the earthquake, the restoration of the damaged buildings and equipment, and the temporary transfer of business activities required contributions amounting to 1,748 million euros (Regione Emilia Romagna, 2017a). With regard to retailing, 2,137 units were involved in the reconstruction process and around half of them have been completed (Regione Emilia Romagna, 2017b).

\subsection{The questionnaire}

After an initial exploratory phase based on focus groups, which involved both retailers affected by the earthquake and representatives of the municipalities and trade associations, a questionnaire was defined, tested and administered to better understand the difficulties that had been encountered and the abilities that had been activated during the earthquake and the recovery phase. The data collection focused on a sample of small retailers whose stores where located in the municipalities of Cavezzo, Mirandola, Novi di Modena and San Felice sul Panaro, chosen as examples of the heavy losses that had been suffered in the area.

To increase the potential response rate, the municipal administrators were involved in identifying the retail activities that survived the disaster. Local authorities also helped in informing possible interviewees about the survey. Three interviewers were appropriately trained and administered the questionnaires, and the data collection was carried out during the February - April 2017 period. 
The questionnaire consists of several sections of questions, which are divided as follows: personal data and descriptive information about the retail entrepreneur and his/her business; possessed skills and competences; organizational resilience dimensions. Each section consists of open questions, which were subsequently reclassified, and questions that were organized on 7-point Likert scales.

The questionnaire was administered to a sample of small retail entrepreneurs, who were selected from those who directly experienced the earthquake and were still in business at the time of the survey. On the basis of the indications that had been provided by the local administrators, all the retailers who satisfied these requirements were contacted; the general feedback was, on average, positive.

\subsection{The sample}

The sample consists of 207 small retail entrepreneurs, $17.4 \%$ of which located in Cavezzo, 42\% in Mirandola, 26.6\% in San Felice sul Panaro, and $14 \%$ in Novi di Modena. $97 \%$ of the interviewees were business owners; the remaining was composed of collaborators or employees.

The nationality is mainly Italian (2.9\% foreigners); women (57.5\%) are more numerous than men $(42.5 \%)$; the average age is 53 years (Tab. 1). Most of the respondents stated they possess a high school diploma (57.1\%), about one third a middle school diploma (37.1\%); remaining cases are graduates $(7.3 \%)$ or possess an elementary school license $(3.9 \%)$. As for experience in the retail sector, on average respondents have over 25 years of experience, with a maximum of 60 and a minimum of 5 . In addition, $10.6 \%$ of the respondents declare they own more than one store, mostly outside the municipality; $17.9 \%$ of the respondents had previous work experience in the retail sector.

Tab. 1: Demographic characteristics of the sample

\begin{tabular}{|l|c|c|c|c|c|c|}
\hline Variables & Freq. & Min & Max & Average & St. Dev. & $\%$ \\
\hline Nationality & 207 & & & & & 100 \\
- Italian & 201 & - & - & - & - & 97.1 \\
- Non-Italian & 6 & & & & & 2.9 \\
\hline Sex & 207 & & & & & 100 \\
- Male & 88 & - & - & - & - & 42.5 \\
- Female & 119 & & & & & 57.5 \\
\hline Education & 205 & & & & & 100 \\
- Elementary School & 8 & & & & & 3.9 \\
- Middle School & 76 & - & - & - & - & 37.1 \\
- High School & 106 & & & & & 51.7 \\
- University & 15 & & & & & 7.3 \\
\hline Age (n. years) & 206 & 27 & 78 & 53.24 & 10.70 & - \\
\hline Experience (n. years) & 205 & 5 & 60 & 25.53 & 12.36 & - \\
\hline
\end{tabular}

Source: authors' elaboration

The main product categories provided by the interviewees (Table 2), reflects small retailers' nature also in quantitative terms.
Elisa Martinelli 


\section{sinergie}

Vol. 37, Issue 1, 2019

Tab. 2: Main product categories provided by the interviewees

\begin{tabular}{|l|c|}
\hline Product categories & $\%$ \\
\hline Apparel, accessories, footwear, underwear, leather goods & 22.7 \\
\hline Food, gastronomy, ice cream, baked goods, fruit and vegetables, meat & 20.3 \\
\hline Antiques, fine arts and decorations, upholstery, glassware & 2.9 \\
\hline Weapons, fishing articles & 1.4 \\
\hline Furniture & 3.9 \\
\hline Gifts and wedding favors & 1.4 \\
\hline Bicycles, spare parts and motorcycle accessories, tires & 1.9 \\
\hline Books and stationary, newspapers, toys & 6.3 \\
\hline Household goods and home linen, small and large appliances & 3.4 \\
\hline Pharmaceutical, and herbal products & 4.8 \\
\hline Hardware, electrical equipment, plastic material & 3.9 \\
\hline Flowers and plants, seeds, gardening machines, feeds, wood & 5.8 \\
\hline Photographs & 1.9 \\
\hline Jewelery, goldsmithery, precious and semiprecious stones & 2.9 \\
\hline Haberdashery, fabrics & 2.4 \\
\hline Optical products & 1.9 \\
\hline Perfumes, products for home care and personal care & 2.4 \\
\hline Health products, orthopedical products & 1.0 \\
\hline Tobacco and lottery tickets & 5.3 \\
\hline Motor vehicles & 1.9 \\
\hline Fuel & 1.4 \\
\hline
\end{tabular}

Source: authors' elaboration

As expected, the dominant category in the sample is apparel, accessories, footwear, underwear, leather goods $(22,7 \%)$; the food and related goods category follows $(20,3 \%)$.

\section{Results}

The literature review reveals that more systematic and quantitative studies are needed to better understand the dimensions that underlie organizational resilience. In this paper we analyzed the impact of sales capabilities, market orientation, the individual approach of small retailers and social capital on organizational resilience. The items related to each dimension have been translated from previously validated scales, adapted to the context of small retailers, and verified in their robustness (Table 3). Using a regression model, the dimensions with the greatest impact on organizational resilience and its intensity level were identified.

In the following table (Tab. 4) reliability measures (i.e. $\alpha$-Cronbach) are reported for each dimension. 
Tab. 3: Investigated dimensions and related items

\begin{tabular}{|c|c|c|c|}
\hline Dimensions & Item & Average & St. Dev. \\
\hline \multirow{7}{*}{$\begin{array}{l}\text { Organizational } \\
\text { Resilience }\end{array}$} & $\begin{array}{l}\text { My company stands straight and preserves its competitive } \\
\text { position on the market }\end{array}$ & 4,86 & 1,452 \\
\hline & $\begin{array}{l}\text { My company is able to identify different ways of solving } \\
\text { problems }\end{array}$ & 5,03 & 1,194 \\
\hline & $\begin{array}{l}\text { My company manages to remain on the market even in } \\
\text { adverse conditions }\end{array}$ & 4,99 & 1,555 \\
\hline & My company does not give up and continues its path & 5,15 & 1,344 \\
\hline & My company rapidly takes action & 4,86 & 1,321 \\
\hline & $\begin{array}{l}\text { My company is able to generate opportunities even from } \\
\text { unfavorable circumstances }\end{array}$ & 4,51 & 1,461 \\
\hline & $\begin{array}{l}\text { My business can quickly implement appropriate actions } \\
\text { when necessary }\end{array}$ & 5,1 & 1,243 \\
\hline \multirow{2}{*}{$\begin{array}{l}\text { Sales } \\
\text { capabilities }\end{array}$} & Revenues (sales) & 3,54 & 1,434 \\
\hline & Ability to increase sales yearly & 3,79 & 1,3 \\
\hline \multirow{4}{*}{$\begin{array}{l}\text { Market } \\
\text { orientation }\end{array}$} & $\begin{array}{l}\text { I usually take up the new opportunities created in new } \\
\text { markets }\end{array}$ & 5,02 & 1,23 \\
\hline & I try often to offer new products or services on the market & 5,6 & 0,996 \\
\hline & I can quickly capture and interpret changes in demand & 5,34 & 1,128 \\
\hline & $\begin{array}{l}\text { I often experiment with new ways of delivering commercial } \\
\text { services }\end{array}$ & 4,91 & 1,292 \\
\hline \multirow{10}{*}{$\begin{array}{l}\text { Retailers' } \\
\text { individual } \\
\text { attitude }\end{array}$} & I am able to adapt to change & 5,71 & 1,187 \\
\hline & I can cope with whatever happens & 5,12 & 1,34 \\
\hline & I always try to find the positive side of things & 5,66 & 1,297 \\
\hline & Coping with stress strengthens me & 4,85 & 1,511 \\
\hline & I tend to recover quickly after an illness or adversity & 5,78 & 1,122 \\
\hline & I can achieve goals despite obstacles & 5,54 & 1,206 \\
\hline & I can stay focused even under stress & 5,51 & 1,11 \\
\hline & Making mistakes does not deter me & 5,56 & 1,077 \\
\hline & I consider myself a strong person & 5,59 & 1,106 \\
\hline & I can handle negative emotions & 5,52 & 1,105 \\
\hline \multirow{9}{*}{ Social capital } & $\begin{array}{l}\text { Who do you think supported you most immediately after } \\
\text { the earthquake? }\end{array}$ & & \\
\hline & Suppliers & 4,71 & 1,986 \\
\hline & Customers & 4,89 & 1,784 \\
\hline & Municipality & 3,11 & 1,754 \\
\hline & Trade associations & 3,39 & 1,977 \\
\hline & Other small retailers & 3,5 & 1,903 \\
\hline & Bank and financial institutions & 2,98 & 1,751 \\
\hline & Friends and acquaintances & 4,82 & 1,962 \\
\hline & Relatives & 4,57 & 2,065 \\
\hline
\end{tabular}

Source: authors' elaboration

Tab. 4: Reliability measures for each dimension

\begin{tabular}{|l|c|c|c|c|}
\hline Dimensions & N. item & Average & Dev. St. & a-Cronbach \\
\hline Organizational resilience & 7 & 4,931 & 0,988 & 0,859 \\
\hline Sales capabilities & 2 & 3,647 & 1,282 & 0,840 \\
\hline Market orientation & 4 & 5,228 & 0,902 & 0,803 \\
\hline Retailers' individual attitude & 10 & 5,467 & 0,904 & 0,910 \\
\hline Social capital & 4 & 4,001 & 1,166 & 0,796 \\
\hline
\end{tabular}

Source: authors' elaboration

Source: authors' elaboration
Elisa Martinelli

Giulia Tagliazucchi

Entrepreneurs' resilience to

natural disasters: a survey in

the retail sector 
sinergie Vol. 37, Issue 1, 2019

A hierarchical regression analysis was then carried out to investigate the impact of different dimensions on organizational resilience. Independent variables were inserted into the relationship at different steps in order to isolate each effect (see Table 5), while analyzing the $\mathrm{R}^{2}$ values. This method allows the assumption of endogeneity to be mitigated and the evaluation of whether the model is sufficiently robust and complete. The regression analysis was performed on a subsample of 201 units, due to missing data in 6 questionnaires. Gender, age and level of education were inserted as control variables in the first model of the hierarchical regression analysis. Gender represents a dummy variable that takes on value 1 for males. Age was divided into four classes (18-35 years; $36-50$ years; $51-65$ years; over 65 years), for each of which a dummy variable was created and took on value 1 if the interviewee falls in what was considered the baseline and the most consistent group from a numerical point of view (51-65 years). Similarly, four classes were also created for the education variable (elementary school, middle school, high school, university); for each of them a dummy variable was created and a baseline selected (high school diploma). Upon analyzing the results of the regression in detail (Table 5), it is valuable to notice, first of all, that the values of $\mathrm{R}^{2}$ are rather high, with the exception of the first model, in which only the control variables were considered. This result is encouraging, considering the originality of the study and the lack of similar empirical research in the literature. In particular, $\mathrm{R}^{2}$ steadily increases from the second model onwards in a highly significant manner $(\mathrm{p} \leq 0.001)$. We can therefore state that the chosen independent variables are a very good starting point for the evaluation of dimensions of organizational resilience in the case of natural disasters, in that they account for approximately $48 \%$ of the total variance of the dependent variable.

Tab. 5: Regression model results

\begin{tabular}{|l|l|l|l|l|}
\hline Models & $\mathrm{R}^{2}$ & Std. Error & Adj. $\mathrm{R}^{2}$ & Durbin-Watson \\
\hline 1 (a) & 0,045 & 0,983 &, 045 & \\
\hline a. Indip. variables: (c), Gender, Age, Education & 0,786 &, 350 & \\
\hline 2 (b) & 0,395 & 0,748 &, 060 & \\
\hline b. Indip. variables: (c), Gender, Age, Education, Sales capabilities, Market orientation \\
\hline 3 (c) & 0,455 &, 027 & 1,92 \\
\hline $\begin{array}{l}\text { c. Indip. variables: (c), Gender, Age, Education, Sales capabilities, Market orientation, } \\
\text { Retailers' individual attitude }\end{array}$ \\
\hline \begin{tabular}{l} 
4 (d) \\
\hline $\begin{array}{l}\text { d. Indip. variables: (c), Gender, Age, Education, Sales capabilities, Market orientation, } \\
\text { Retailers' individual attitude, Social capital }\end{array}$
\end{tabular}
\end{tabular}

Source: authors' elaboration

Looking closely at the effect of each dimension on organizational resilience (Tab. 6), it should be observed that control variables are nonsignificant, with the exception of the dummy variable relating to the educational level of university degree $(p<0,05)$. We may then assume that the entrepreneurs' socio-demographic characteristics tend to be irrelevant in affecting organizational resilience. However, small retail entrepreneurs who complete their university education tend to be more resilient than those with lower levels of education. 
Tab. 6: Regression coefficients

\begin{tabular}{|c|c|c|c|c|}
\hline Models & $\beta$ & Std. Error & Sign. & $\begin{array}{l}\text { natural disasters: a survey in } \\
\text { the retail sector }\end{array}$ \\
\hline 1 (a) & & & & \\
\hline $\mathrm{C}$ & & 0,16 & 0 & \\
\hline Age (18-35) Dummy 1 & 0,045 & 0,322 & 0,544 & \\
\hline Age (36-50) Dummy 2 & 0,107 & 0,162 & 0,168 & \\
\hline Age (over 65) Dummy 3 & 0,106 & 0,24 & 0,172 & \\
\hline Education - elementary school Dummy & $-0,101$ & 0,387 & 0,19 & \\
\hline Education - middle school Dummy & 0,055 & 0,158 & 0,478 & \\
\hline Education - University Dummy ${ }^{* *}$ & 0,157 & 0,283 & 0,033 & \\
\hline Gender & $-0,028$ & 0,145 & 0,701 & \\
\hline 2 (b) & & & & \\
\hline $\mathrm{C}$ & & 0,362 & 0 & \\
\hline Age (18-35) Dummy 1 & 0,048 & 0,263 & 0,427 & \\
\hline Age (36-50) Dummy 2 & 0,077 & 0,131 & 0,216 & \\
\hline Age (over 65) Dummy 3 & 0,1 & 0,192 & 0,109 & \\
\hline Education - elementary school Dummy & $-0,031$ & 0,311 & 0,621 & \\
\hline Education - middle school Dummy & 0,033 & 0,127 & 0,593 & \\
\hline Education - University Dummy ${ }^{* *}$ & 0,14 & 0,226 & 0,018 & \\
\hline Gender & 0,039 & 0,117 & 0,505 & \\
\hline Sales capabilities* & 0,303 & 0,047 & 0 & \\
\hline Market orientation $^{*}$ & 0,438 & 0,065 & 0 & \\
\hline $3(\mathrm{c})$ & & & & \\
\hline $\mathrm{C}$ & & 0,387 & 0,148 & \\
\hline Age (18-35) Dummy 1 & 0,07 & 0,251 & 0,231 & \\
\hline Age (36-50) Dummy 2 & 0,053 & 0,125 & 0,377 & \\
\hline Age (over 65) Dummy 3 & 0,08 & 0,184 & 0,177 & \\
\hline Education - elementary school Dummy & $-0,069$ & 0,299 & 0,246 & \\
\hline Education - middle school Dummy & 0,012 & 0,121 & 0,841 & \\
\hline Education - University Dummy ${ }^{\star *}$ & 0,143 & 0,215 & 0,011 & \\
\hline Gender & 0,005 & 0,113 & 0,934 & \\
\hline Sales capabilities ${ }^{*}$ & 0,257 & 0,046 & 0 & \\
\hline Market orientation $^{*}$ & 0,313 & 0,069 & 0 & \\
\hline Retailers' individual attitude ${ }^{*}$ & 0,291 & 0,07 & 0 & \\
\hline $4(\mathrm{~d})$ & & & & \\
\hline $\mathrm{C}$ & & 0,395 & 0,621 & \\
\hline Age (18-35) Dummy 1 & 0,065 & 0,245 & 0,253 & \\
\hline Age (36-50) Dummy 2 & 0,041 & 0,122 & 0,483 & \\
\hline Age (over 65) Dummy 3 & 0,096 & 0,18 & 0,1 & \\
\hline Education - elementary school Dummy & $-0,047$ & 0,295 & 0,426 & \\
\hline Education - middle school Dummy & 0,037 & 0,12 & 0,526 & \\
\hline Education - University Dummy ${ }^{\star *}$ & 0,139 & 0,21 & 0,011 & \\
\hline Gender & $-0,018$ & 0,111 & 0,747 & \\
\hline Sales capabilities* & 0,221 & 0,045 & 0 & \\
\hline Market orientation* & 0,297 & 0,068 & 0 & \\
\hline Retailers' individual attitude ${ }^{*}$ & 0,283 & 0,068 & 0 & \\
\hline Social capital ${ }^{* *}$ & 0,179 & 0,048 & 0,002 & \\
\hline
\end{tabular}

Elisa Martinelli

Elisa Martinelli

Entrepreneurs' resilience to

natural disasters: a survey in

1 (a)

Age (18-35) Dummy 1

0,107

0,162

0,106

0,387

0,19

0,055

0,283

0,033

Gender

Age (18-35) Dummy 1

Education - elementary school Dummy

Gender

3 (c)

Age (18-35) Dummy 1

Age (36-50) Dummy 2

Age (over 65) Dummy 3

Education - elementary school Dummy

Education - middle school Dummy

Education - University Dummy

Sales capabilities

Market orientation

Retailers individual attitude

Source: authors' elaboration 
sinergie Vol. 37, Issue 1, 2019

By adding the dimensions of sales capabilities and market orientation, the regression model becomes highly significant. Similarly, in the further steps of the hierarchical regression analysis in which individual resilience and then social capital are added, $\mathrm{R}^{2}$ significantly increases. All independent variables have a positive and significant effect ( $\mathrm{p}$-value $<0.001$ ), just as the contribution of university education remains positive and significant. In disentangling the contribution of each dimension to the organizational resilience construct, it should be noted that the dimension market orientation features a higher coefficient (value $\beta$ ), and therefore has a greater impact than the other independent variables in all the three models. Another dimension showing a strong impact on organizational resilience is represented by the retailers' individual attitude, which entered in the third model and was confirmed in the fourth. These results, in general, appear to be coherent and consistent with the proposed model and with what is stated in the academic literature on the topic.

The results here presented emphasize the centrality of the individual level of analysis, focused on small retailers who face a natural disaster, also from a systemic all-encompassing perspective looking at different determinants of the organizational resilience construct. Most of the studies that focus on retail resilience are by far related to the urban retail stream of research; within this perspective, resilience is then defined as an evolutionary and dynamic process rather than system characteristics (Martin, 2012; Wrigley and Dolega, 2011). Moreover, the conceptualization of resilience is similar to that used in the socio-ecological perspective that posits a spontaneous reorganization of small retail businesses (Lang, 2011), in contrast to the potential effectiveness of a controlled reorganization based on the coordination and direction of institutional actors (Dolega and Celińska-Janowicz, 2015). These perspectives are balanced in the studies proposed by Erkip et al. (2014), who distinguish between "spontaneous" and "planned" resilience. The former is defined as the reaction strategy that small retail entrepreneurs undertake as individuals; conversely, the latter presupposes the involvement of institutions at a local and community level, in a systemic perspective. Within the literature's state-of-the-art, the proposed model integrates and jointly analyzes, on the one hand, the individual and personal skills of small retail entrepreneurs and, on the other hand, the role of social capital. It is therefore evident that entrepreneurial skills, namely sales capabilities and market orientation, along with a strong entrepreneur's personal attitude towards resilience, are the driving forces of retail recovery, which is defined as spontaneous by Erkip et al. (2014). Furthermore, individual characteristics become important determinants of organizational resilience, which is therefore defined as a property and a capacity. However, this reaction at the individual level is further strengthened by the presence of social capital, thus allowing for further reflections on the role of institutions and the local community, and offering hints in order to integrate the level of spontaneous individual response with that of a more planned and controlled response that is steered by a higher level of aggregation. 


\section{Conclusions and implications}

Natural disasters are events of increasing manifestation in their frequency and intensity, particularly threatening for business continuity and require distinctive management skills, improvisation and the reconfiguration of resources in order to be overcome. However, to put a resilient response in place, it is necessary to understand the dimensions that contribute to enhancing organizational resilience more in detail.

Indeed, the first contribution of this analysis consists in a preliminary reflection on determinants of the organizational resilience in the specific case of small retail entrepreneurs, with particular reference to the market, sales, as well as individual and relational competences. The performed empirical study integrates current knowledge on organizational resilience in retail businesses by disentangling the effect of specific dimensions of resilience in the context of small retail entrepreneurs who have been put to the test by a natural disaster of high impact like an earthquake. Secondly, the analysis contributes to the debate on the effects of natural disasters on business activities, an area that still appears to be scantly investigated (Liu et al., 2012; Battisti and Deakins, 2017). Finally, the contribution of applying the topic of organizational resilience to a scarcely investigated context area, such as that of small retailing is also relevant.

In the aftermath of the earthquake, the small retail entrepreneurs of the affected region had to face devastating effects and consequences and cope with new challenges to reposition their commercial activity. The small retail entrepreneurs who showed greater resilience were those who were aware of the altered economic conditions of the community and of a decrease in demand caused by population migration, and therefore were able to detect and interpret the changed consumers' needs. Indeed, sales capabilities and market orientation are highlighted as organizational resilience dimensions.

In addition to the capabilities that are directly related to the entrepreneurs' professional and business profile, an extremely important role is played by the individual resilience of the entrepreneur him/ herself and by his/her personal ability and attitude when responding to unexpected events. Similarly, other studies show how it is possible to adapt to the changing environment and an unexpected event through self-control and self-efficacy (Markman et al., 2005). Moreover, individual resilience is enhanced by integrating previous experience with one's own knowledge and resources (Ayala and Manzano, 2014; Cooper et al., 2004).

At the individual level of analysis, the positive contribution of higher education emerged as related to organizational resilience. The small retail entrepreneurs who attained a university degree show higher levels of resilience than those who reached lower levels of education. As a consequence, it is important to support and promote advanced education even in a sector that is traditionally recognized as a safe-haven sector like the retailing one.

Finally, the role of social capital emerged as being important (Aldrich and Meyer, 2015; Lengnick-Hall et al., 2011), especially in the case of small businesses with scarce resources in terms of money, time and human 
sinergie Vol. 37, Issue 1, 2019

capital (Van Gils, 2005). Indeed, the support of their network of formal and informal relationships can become an important source of information and support, as well as of concrete operational aid, also in economic terms.

The implications stemming from the present study are twofold. Firstly, as a managerial implication, more in-depth knowledge of the determinants of organizational resilience allows one to better assess on which factors to invest more and what type of knowledge and capabilities are relevant in the face of unforeseen events. Secondly, the study offers new recommendations for public policies by means of evidence that the successful recovery processes of a community is based on the resilience of the individuals and organizations that make up the community (McManus et al., 2008). Greater awareness of the role of retail in the aftermath of a natural disaster would help in addressing reconstruction policies at an urban level. Ultimately, the experience that was achieved by the small retail entrepreneurs who are affected by the 2012 earthquake in Emilia, could be an example and a guide in the unfortunate event of future natural disasters.

Despite the useful contributions that the current study offers to the scientific community, entrepreneurs and the institutions and organizations that support business development, some limitations are present. Firstly, its explorative nature limits the possibility of generalizing the findings, as it took a limited number of possible determinants of organizational resilience into consideration. Future studies could extend the analysis to other antecedents, such as tangible resources of the company and/or additional skills compared to those specifically included in this study, so as to understand if a different endowment of resources and capabilities could lead to different outcomes in terms of organizational resilience when a natural disaster occurs. Secondly, the regression analysis that was carried out provides a reading of the relationships among variables, but other methodologies - such as structural equation modeling (SEM), for instance - could provide a more solid and complete understanding of the model effects.

\section{References}

ADNKRONOS (2017), "Da terremoti a alluvioni, oltre 49mld di danni in 15 anni, 10 settembre", testo disponibile al sito http://www.adnkronos. com/soldi/economia/2017/09/10/terremoti-alluvioni-oltre-mld-dannianni_7AAC3gmZqlopURxIeB3GtN.html?refresh_ce.

ADLER P., KWON S. (2002), "Social capital: prospects for a new concept", Academy of Management Review, vol. 27, n. 1, pp. 17-40.

ALESCH D.J., HOLLY J.N., MITTLER E., NAGY R. (2001), Organizations at risk: What happens when small businesses and not-for-profits encounter natural disasters, Public Entity Risk Institute PERI.

BAKER S.M., HUNT D.M., RITTENBURG T.L. (2007), "Consumer vulnerability as a shared experience: Tornado recovery process in Wright, Wyoming", Journal of Public Policy and Marketing, vol. 26, n. 1, pp. 6-19.

BATTISTI M., DEAKINS D. (2017), "The relationship between dynamic capabilities, the firm's resource base and performance in a post-disaster environment", International Small Business Journal, vol. 35, n. 1, pp. 78-98. 
BHAMRA R., DANI S., BURNARD K. (2011), "Resilience: the concept, a literature review and future directions", International Journal of Production Research, vol. 49 , n. 18 , pp. 5375-5393.

CHAMLEE-WRIGHT E., STORR V.H. (2009), “There's no place like New Orleans”: Sense of place and community recovery in the Ninth Ward after Hurricane Katrina”, Journal of Urban Affairs, vol. 31, n. 5, pp. 615-634.

CHANG S.E., FALIT-BAIAMONTE A. (2002), "Disaster vulnerability of businesses in the 2001 Nisqually earthquake", Global Environmental Change Part B: Environmental Hazards, vol. 4, n. 2, pp. 59-71.

CONNOR K.M., DAVIDSON J.R. (2003), Development of a new resilience scale: The Connor-Davidson Resilience Scale (CD-RISC)", Depression and Anxiety, vol. 18, n. 2, pp. 76-82.

CUTTER S.L., BARNES L., BERRY M., BURTON C., EVANS E., TATE E., WEBB J. (2008), "A place-based model for understanding community resilience to natural disasters", Global environmental change, vol. 18, n. 4, pp. 598-606.

DAHLES H., SUSILOWATI T.P. (2015), "Business resilience in times of growth and crisis", Annals of Tourism Research, vol. 51, marzo, pp. 34-50.

DEITCH E., COREY C. (2011), "Predicting long-term business recovery four years after Hurricane Katrina”, Journal of Contingencies and Crisis Management, vol. 19, n. 3, pp. 169-181.

DOLEGA L., CELIŃSKA-JANOWICZ D. (2015), "Retail resilience: A theoretical framework for understanding town centre dynamics", Studia Regionale $i$ Lokalne, vol. 16, n. 60, pp. 8-31.

DUBINI P., ALDRICH H. (1991), "Personal and Extended Networks are Central to the Entrepreneurial Process", Journal of Business Venturing, vol. 6, n. 5, pp. 305-313.

ERKIP F., KIZILGÜN Ö., AKINCI G.M. (2014), "Retailers' resilience strategies and their impacts on urban spaces in Turkey", Cities, vol. 36, pp. 112-120.

FRANK B., SCHVANEVELDT S.J. (2016), "Understanding consumer reactions to product contamination risks after national disasters: The roles of knowledge, experience, and information sources", Journal of Retailing and Consumer Services, vol. 28, pp. 199-208.

HOLLING C.S. (1973), "Resilience and stability of ecological systems", Annual Review of Ecology and Systematics, vol. 4, n. 1, pp. 1-23.

KANTUR D., İŞERI-SAY A. (2012), "Organizational resilience: A conceptual integrative framework", Journal of Management and Organization, vol. 18, n. 6, pp. 762-773.

KANTUR, D., İŞERI-SAY, A. (2015), "Measuring organizational resilience: a scale development", Journal of Business, Economic and Finance, vol. 4, n. 3, pp. 456-472.

KROLL C.A., LANDIS J.D., SHEN Q. (1990), "The economic impacts of the Loma Prieta earthquake: A focus on small business", Berkeley Planning Journal, vol. 5, n. 1, pp. 39-58.

LANG T. (2011), "Urban resilience and new institutional theory - A happy couple for urban and regional studies", in Muller B., Urban and regional resilience: How do cities and regions deal with change?, Berlin, Springer-Verlag, pp. 15-24.

LENGNICK-HALL C.A., BECK T.E. (2003), "Beyond bouncing back: The concept of organizational resilience", National Academy of Management Meetings, Seattle, WA.
Elisa Martinelli

Giulia Tagliazucchi

Entrepreneurs' resilience to

natural disasters: a survey in

the retail sector 


\section{sinergie}

Vol. 37, Issue 1, 2019

LENGNICK-HALL C.A., BECK T.E., LENGNICK-HALL M.L. (2011), “Developing a capacity for organizational resilience through strategic human resource management", Human Resource Management Review, vol. 21, n. 3, pp. 243255.

LINNENLUECKE M.K. (2017), "Resilience in business and management research: A review of influential publications and a research agenda", International Journal of Management Reviews, vol. 19, n. 1, pp. 4-30.

LIU C., BLACK W.C. (2011), "Post-disaster consumer coping: consumption adjustment", Asian Pacific Advances in Consumer Research, vol. 9, in Yi Z., Xiao J.J., Cotte J., Price L., Association for Consumer Research, Duluth, MN, pp. 214-221.

LIU C., BLACK W.C., LAWRENCE F.C., GARRISON M.E.B. (2012), "Post-disaster coping and recovery: The role of perceived changes in the retail facilities", Journal of Business Research, vol. 65, n. 5, pp. 641-647.

MAKKONEN H., POHJOLA M., OLKKONEN R., KOPONEN A. (2014), "Dynamic capabilities and firm performance in a financial crisis", Journal of Business Research, vol. 67, n. 1, pp. 2707-2719.

MARKMAN G.D., BARON R.A., BALKIN D.B. (2005), "Are perseverance and self-efficacy costless? Assessing entrepreneurs' regretful thinking", Journal of Organizational Behavior, vol. 26, n. 1, pp. 1-19.

MARTIN R. (2012), "Regional economic resilience, hysteresis and recessionary shocks", Journal of Economic Geography, vol. 12, n. 1, pp. 1-32.

MARTINELLI E., TAGLIAZUCCHI G., MARCHI G. (2018), “The Resilient Retail Entrepreneur: Dynamic Capabilities for Facing Natural Disasters", International Journal of Entrepreneurial Behavior and Research, vol. 24, $\mathrm{n}$. 7, pp. 1222-1243

MCMANUS S., SEVILLE E., VARGO J., BRUNSDON D. (2008), "Facilitated process for improving organizational resilience", Natural Hazards Review, vol. 9, n. 2, pp. 81-90.

MESZAROS J. (2002), "Effects of the 2001 Nisqually earthquake on small businesses in Washington State", report prepared for the Economic Development Administration, US Department of Commerce, Seattle Regional office.

PAL R., TORSTENSSON H., MATTILA H. (2014), "Antecedents of organizational resilience in economic crises - an empirical study of Swedish textile and clothing SMEs", International Journal of Production Economics, vol. 147, part B, pp. 410-428.

PARKER C.F., STERN E.K., PAGLIA E. (2009), "Preventable catastrophe? The hurricane Katrina disaster revisited", Journal of Contingencies and Crisis Management, vol. 17, n. 4, pp. 206-220.

PEARSON M., LAWRENCE K., HICKMAN T. (2011), "Retail recovery from natural disasters: New Orleans versus eight other United States disaster sites", The International Review of Retail, Distribution and Consumer Research, vol. 21, n. 5, pp. 415-444.

PETERSON M., EKIC, A., HUNT D.M. (2010), "How the poor in a developing country view business' contribution to quality-of-life 5years after a national economic crisis", Journal of Business Research, vol. 63, n. 6, pp. 548-558.

REGIONE EMILIA ROMAGNA (2012), Report "A sei mesi dagli eventi del 20 e 29 maggio. I danni del terremoto e le politiche messe in campo per affrontare l'emergenza e la ricostruzione", Novembre.

REGIONE EMILIA ROMAGNA (2017a), Report “L’Emilia dopo il sisma. Report su cinque anni di ricostruzione”, Maggio. 
REGIONE EMILIA ROMAGNA (2017b), Dati Mude, aggiornamento 31 Agosto, disponibile al sito http://www.regione.emilia-romagna.it/terremoto/ numeri/mude.

RUNYAN R.C. (2006), "Small business in the face of crisis: Identifying barriers to recovery from a natural disaster", Journal of Contingencies and Crisis Management, vol. 14, n. 1, pp. 12-26.

SUTCLIFFE K.M., VOGUS T.J. (2003), "Organizing for resilience", Positive Organizational Scholarship, in Cameron K.S., Dutton J.E., Quinn R.E. (Eds), Positive organizational scholarship: Foundations of a new discipline, Berrett-Koehler, San Francisco, CA, pp. 94-110.

TEECE D.J. (2012), “Dynamic capabilities: Routines versus entrepreneurial action”, Journal of Management Studies, vol. 49, n. 8, pp. 1395-1401.

TIERNEY K.J. (1997), "Business Impacts of the Northridge Earthquake”, Journal of Contingencies and Crisis Management, vol. 5, n. 2, pp. 87-97.

VAN GILS A. (2005), "Management and governance in Dutch SMEs", European Management Journal, vol. 23, n. 5 pp. 583-589.

VERREYNNE M.L., HINE D., COOTE L., PARKER R. (2016), “Building a scale for dynamic learning capabilities: The role of resources, learning, competitive intent and routine patterning", Journal of Business Research, vol. 69, n. 10, pp. 4287-4303.

WASILESKI G., RODRIGUEZ H., DIAZ W. (2011), "Business closure and relocation: a comparative analysis of the Loma Prieta earthquake and Hurricane Andrew", Disasters, vol. 35, n. 1, pp. 102-129.

WEBB G.R., TIERNEY K.J., DAHLHAMER J.M. (2000), "Businesses and disasters: Empirical patterns and unanswered questions", Natural Hazards Review, vol. 1, n. 2, pp. 83-90.

WILLIAMS T.A., GRUBER D.A., SUTCLIFFE K.M., SHEPHERD D.A., ZHAO E.Y. (2017), "Organizational response to adversity: fusing crisis management and resilience research streams", Academy of Management Annals, vol. 11, n. 2, pp. 733-769.

WALKER B., HOLLING C.S., CARPENTER S., KINZIG A, (2004), "Resilience, adaptability and transformability in social-ecological systems", Ecology and Society, vol. 9, n. 2, pp. 5. [online] URL: http://www.ecologyandsociety.org/ vol9/iss2/art5/

WRIGLEY N., DOLEGA L. (2011), "Resilience, fragility, and adaptation: new evidence on the performance of UK high streets during global economic crisis and its policy implications", Environment and Planning A, vol. 43, n. 10, pp. 2337-2363.

ZHANG Y., LINDELL M.K., PRATER C.S. (2009), "Vulnerability of community businesses to environmental disasters", Disasters, vol. 33, n. 1, pp. 38-57.

\section{Academic or professional position and contacts}

\section{Elisa Martinelli}

Associate Professor of Management

University of Modena e Reggio Emilia - Italy

e-mail: elisa.martinelli@unimore.it.

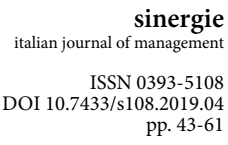

Giulia Tagliazucchi

Phd in Management

University of Modena e Reggio Emilia - Italy

e-mail: giulia.tagliazucchi@unimore.it

e retail sector 